\title{
Correlation between glaze-colors and structural properties of the HIZEN celadons produced in the Edo period of Japan, by means of X-ray diffraction (I)
}

\section{(Correlação entre cores de esmaltes e propriedades estruturais de celadons Hizen produzidos no período Edo do Japão, por meio de difração de raios $X(I))$}

\author{
M. Hidaka ${ }^{1}$ K. Ohashi ${ }^{2}$, R. P. Wijesundera ${ }^{1,6}$, L. S. R. Kumara ${ }^{1}$ M. Watanabe ${ }^{3}$, K. Koga ${ }^{4}$, \\ Jae-Young Choi ${ }^{5}$, N. E. Sung ${ }^{5}$, Y. J. Park \\ ${ }^{1}$ Department of Physics, Graduate School of Science, Kyushu University, Fukuoka 812-8581, Japan \\ ${ }^{2}$ The Kyushu Ceramic Museum, Arita, Saga, 844-8585, Japan \\ ${ }^{3}$ Center of Advanced Instrumental Analysis, Kyushu University, Fukuoka 819-0395, Japan \\ ${ }^{4}$ Advanced Instruments Centre, Kyushu Sangyo University, Japan \\ ${ }^{5}$ Beamline Department, Pohang Accelerator Laboratory, Pohang University of Science and Technology, San31, \\ Hyoja-doing, Pohang, 790-784, Korea \\ ${ }^{6}$ Department of Physics, University of Kelaniya, Kelaniya, Sri Lanka \\ hidaka@phys.kyushu-u.ac.jp
}

\begin{abstract}
HIZEN celadons produced at Arita and Imari areas in Japan from 1630's to 1790's (Edo period) have been investigated by means of X-ray fluorescence analysis, and X-ray diffraction and X-ray absorption spectra using synchrotron radiation. It is found that, in the HIZEN celadons, the color brightness of the celadon glazes depends on the structural property of the raw basic ceramics taken at Imaizumi (Arita) and Ohkwachi (Imari), where the former is mainly Quartz- $\mathrm{SiO}_{2}$, and the later is Sanidine $\left((\mathrm{K}, \mathrm{Na}) \mathrm{Si}_{3} \mathrm{O}_{8}\right)$. It is confirmed that $\mathrm{CaCO}_{3}$ of natural wood ash added artificially into the raw celadon ceramics makes a glassy glaze on the surface of the basic body of the HIZEN celadons. Transition-metal ions $(\mathrm{Cr}, \mathrm{Cu}, \mathrm{Zn})$ of very small amount are detected in the celadon glazes, in addition to $\mathrm{Fe}$ and $\mathrm{Mn}$ of small amount. It is considered that $\mathrm{Cu}$ and $\mathrm{Cr}$ are related to the color brightness of green-brown and blue-green in the HIZEN celadon glazes, respectively.
\end{abstract}

Keywords: HIZEN celadons, celadon glaze, microstructure.

\section{Resumo}

Celadons (http://www.ceramicanorio.com/aprendendoourelembrando/celadon/celadon.html) Hizen produzidos nas áreas de Arita e Imari no Japão nos anos de 1630 a 1790 (periodo Edo) foram investigados por meio de análise de fluorescência de raios $X$, difração de raios $X$ e espectros de absorção usando radiação síncrotron. Foi descoberto que nos celadons Hizen o brilho na coloração dos esmaltes celadon depende da propriedade estrutural da matéria-prima cerâmica extraída em Imaizumi (Arita) e Ohkwachi (Imari), onde a primeira é principalmente quartzo-SiO, e a última é um feldspato ((K,Na) $\mathrm{Si}_{3} \mathrm{O}_{8}$ ). Foi confirmado que $\mathrm{CaCO}_{3}$ da cinza da madeira natural adicionada artificialmente na matéria-prima cerâmica celadon produz um esmalte vítreo na superficie do corpo básico dos celadons Hizen. Uma quantidade muito pequena de ions de metal de transição ( $\mathrm{Cr}, \mathrm{Cu}, \mathrm{Zn}$ ) foi detectada nos esmaltes de celadons, alem de pequeno teor de Fe e Mn. Considerase que $\mathrm{Cu}$ e Cr estão relacionados com o brilho na coloração verde-marron e azul-verde nos esmaltes do celadon Hizen, respectivamente.

Palavras-chave: celadons Hizen, esmalte de celadon, microestrutura.

\section{INTRODUCTION}

In 1630's to 1750's (the early Edo period), the HIZEN colored porcelains were produced at Arita and Imari areas, which were under the rule of Nabeshima domain in HIZENHan at that time of the Edo period (at present, Arita and Imari areas in Saga prefecture of Kyushu island, Japan). Korean potters discovered raw materials for the porcelain ceramics of 
high-quality at Arita area in 1610's. The porcelain ceramics of white-color is ferromagnetic, called Hakujikou, and collected specially at a small mountain, Izumiyama, sited in the center of Arita. The HIZEN colored porcelains show elegant and bright patterns (flowers, weedy grasses, threes) on the white or milky-white porcelain basic body with several kinds of colored enamels in the overglazes and with blue enamel on the transparent underglaze. Especially, the colored patterns were distributed non-symmetrically in the widely white or milky-white space on the porcelain surface. It is known that the HIZEN colored porcelains are classified by four kinds of porcelains: Shoki-Iroe (Kokutani-style), Kakiemon-style, Kinran-style, and Nabeshima ware [1-8]. The HIZEN colored porcelains had been exported from the later $17^{\text {th }}$ century and were estimated to be very famous for interior decorations and dinner-sets in Europe, as Chinese porcelains.

At Arita, porcelains, called "Shoki-Imari", were produced by a Korean porcelain technique in 1610 1640's. From 1640 1650's, the porcelains having the blue-colored underglazes and the overglazes of several colors were produced by the porcelain technique due to Keitokuchin-kiln (China). At the time, celadons were also made due to Ryusenkiln (China) [9, 10]. The HIZEN celadons were produced at Arita area in 1630 1660's, and the celadon glaze was completed in 1670's [11]. In 1630 1650's, MITUNOMATA celadons having the elegant and bright glaze were also produced at Mitunomata of Hasami, which is about $10 \mathrm{~km}$ away from Arita [12,13]. After 1700's, the quality of celadon glaze was gradually declined [14]. In order to do quickly the mass production of the exporting HIZEN colored porcelains at the Arita areas, the Nabeshima domain gathered special kilns, called AKAEYA, at AKAE-MACHI localized at a small area in the center of Arita in 1660's. The AKAEYA carried out professionally to paint the overglazes and heat the colored porcelains at high-temperature. Thus, it was deduced that the declination of the celadon technique was affected by the mass production of the HIZEN colored porcelains at Arita. However, the Nabeshima-domain kiln, called Odouguyama, was transferred from Nangawara (Arita) to Okawachi (Imari) in 1673-1681's, where the later is about $10 \mathrm{~km}$ away from Arita. The HIZEN celadons of high-quality were continuously produced at Imari, and the celadon technique has been succeeded to the modern Nabeshima celadons, as Choshun kiln sited at Ohkawachi.

The HIZEN celadons are grouped by a monochromatic glaze and a blue-color underglaze or a rust glaze on the basic body of the porcelain ceramics [3, 8, 11-13]. However, the glazes of the HIZEN celadons produced in the early 17th century are semitransparent, non-uniform, and show wider color from light green-brown, black green-brown, dark brown, green-brown, green. This means that the thermal treatment at high-temperature of about 1200 to $1250{ }^{\circ} \mathrm{C}$ was not stable in the used kilns. It is interested that, from 1630's, some HIZEN celadons show the underglaze patterns painted on the basic body. It was considered that Japanese porcelains are always based on progenitor styles of Chinese and Korean ones. However, progenitor styles of the celadons, which were combined with underglazed cobalt-blue color or lapis color, were produced in the middle 17th century [3, 4, 8, 11-13, 15]. Such celadons cannot be clearly found in China and Korea at that time.

It is empirically known that the iron oxides in the celadon glaze show blue-green color under the deoxidizing thermal treatment at high-temperature of about 1200 to $1250{ }^{\circ} \mathrm{C}$. The celadon glaze changes gradually its color from yellowbrown to black color, as increasing the iron oxides under the deoxidizing thermal treatment. J. S. Larid (1918) [16] and R. R. Hunghan (1950) [17] reported that the blue-green color of the celadon glazes is induced by chemical reaction from $\mathrm{Fe}_{2} \mathrm{O}_{3}$ to $\mathrm{FeO}$ in the celadon glazes under the deoxidizing thermal treatment.

Recently, we have studied the structural and electronic properties of the red-colored overglazes on the HIZEN colored porcelains, produced at Arita areas from the $17^{\text {th }}$ to $18^{\text {th }}$ century, by means of X-ray diffraction (XRD) and X-ray absorption spectrum (XAS), using synchrotron radiation [1820]. In the present paper, we report the technical and historical correlations among the celadon glazes of the HIZEN celadons produced in the Edo period by means of the same methods of the XRD and XAS using synchrotron radiation, in addition to $\mathrm{X}$-ray fluorescence analysis.

\section{MATERIALS}

As described above, the HIZEN celadons were produced at the Arita areas of Arita, Hasami, and Ohkwachi in the north region of Kyushu island (Japan), and are closed to neighbor country of Korea. The areas are localized in the small area of about $20 \mathrm{~km}$ in diameter, and geologically give the raw ceramics having similar oxides of mainly $\mathrm{SiO}_{2}$ and $\mathrm{Al}_{2} \mathrm{O}_{3}$ and a small amount of other extra oxides $\mathrm{K}_{2} \mathrm{O}, \mathrm{Na}_{2} \mathrm{O}, \mathrm{CaO}, \mathrm{MgO}$, $\mathrm{Fe}_{2} \mathrm{O}_{3}$. Thus, it is expected that the difference of the extra oxides partially relates to characteristic color modulation of the HIZEN celadons. In the present investigations, the oxide components of the raw ceramics were studied by means of $\mathrm{X}$-ray fluorescence emitted from the ceramics, when the X-ray beams were emitted from a Cr-target of the ordinary X-ray source $(50 \mathrm{kV}, 50 \mathrm{~mA})$. Table I shows a ratio (wt.\%) of the oxide components in the raw basic ceramics and the raw celadon ceramics at Izumiyama (Arita), Mitunomata (Hasami), and Ohkawachi (Imari), where we will describe about a material of Isubai later. It is found that the raw ceramics include mainly $\mathrm{SiO}_{2}$ and $\mathrm{Al}_{2} \mathrm{O}_{3}$, in addition to the extra oxides, though each ratio depends on the mining place of the raw ceramics. The amount of $\mathrm{Fe}_{2} \mathrm{O}_{3}$ in the Izumiyama celadon ceramics is slightly larger than its basic-body ceramics of white-color, called "Hakujikou".

In the present investigations, the used specimens were 12 broken pieces of the monochromatic HIZEN celadons (Photo $1(\mathrm{a})$ to $(\ell)$ ) produced in 1630's to 1790's at Arita areas (Arita, Yamauchi) and Imari, and 2 ones of the modern Nabeshima celadons (Photo 1(m) and (n)) produced by Choshun kiln sited at Ohkawachi (Imari) in 2007; Photo 1(a) and (f): incense burner, (b): handing salt plate, (c)-(e), (g)-(i),(m): plate, (j): 


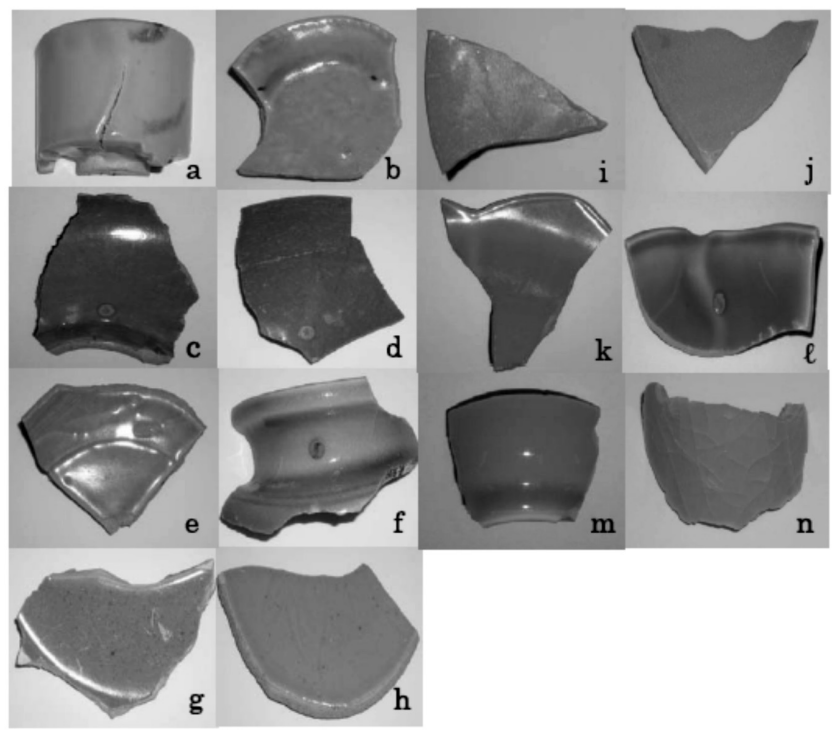

Photo 1: Broken pieces of the HIZEN celadons taken at Arita and Ohkawachi (Imari), and the modern Nabeshima celadons produced by Choshun kiln; (a) Kamanotsuji (1630-1640's), (b) Kamanotsuji (1630-1640's), (c) Hyakuken (1630-1640's), (d) Hyakuken (16301640's), (e) Chokichidani (1655-1660's), (f) Chokichidani (16551660's). (g) Maruo (1650-1660's), (h) Shimoshirakawa (16551660's), (i) Nabeshima-domain kiln (1690-1720's), (j) Nabeshimadamain kiln (1690-1720's), (k) Higuchi (1760-1790's), ( $\ell$ ) Higuchi (1760-1790's), (m) Choshun kiln (2007), (n) Choshun kiln (2007). [Foto 1: Peças quebradas de celadons Hizen retiradas em Arita e Ohkawachi (Imari), e os modernos celadons produzidos em forno Chosun.]

flower vase, (n): tea pot. The HIZEN celadons in Photo 1(a) and $(\ell)$ were collected at the ancient kilns of Kamanotsuji (Yamauchi), Hyakuken (Yamauchi), Chokichidani (Arita), Maruo (Arita), Shimoshirakawa (Arita), Higuchi (Arita), and Nabeshima-domain kiln called Nabeshima Odouguyama (Ohkwachi at Imari). All of the kilns are famous and historical kilns in the Edo period. Ohkawachi (Imari) is about $10 \mathrm{~km}$ away from Arita, while Yamauchi is about $5 \mathrm{~km}$ away from Izumiyama at Arita. After Korean potters discovered the high-quality porcelain ceramics at the small mountain of Izumiyama, which is sited at the center of Arita in 1610's, it was considered that the kilns at Yamauchi area used the Izumiyama ceramics. The broken pieces of the Nabeshima celadons in Photo 1(i) and (j) were made at Ohkawachi Odougu-yama. The Nabeshima wares including the celadons show excellently elegance and brightness, since the wares were gifts only to the Tokugawa Shogun (Edo period) [3, 8]. In Photo 1, the glazes of the HIZEN celadons (Yamauchi) produced before 1650's show partially light-shade color and non-uniform to those of the HIZEN celadons (Arita) produced in 1650's-1660's. On the other hand, the glaze color of the HIZEN celadons (Ohkawachi) is blue-green and is also different to those of the celadons produced at Yamauchi and Arita. It is deduced that the glaze color and its uniformity depend on the raw materials of the used raw ceramics or the technical difference among the potters working at each kilns. However, in Table I, there is not so large difference of the oxide components in the celadon ceramics and the basic-body ceramics of Izumiyama and Ohkawachi, as shown in Table I.

The broken pieces of the HIZEN celadons in photo 1 were rented from at the public museum are very important cultural assets in Japan. Thus, in the present investigations, we were strongly requested to use nondestructive methods for studying the structural and electronic properties of the present celadons. In order to study the oxide components in the celadon glazes, we used an energy dispersive-type X-ray fluorescence analyzer (Simazu-EDX 800) having lower current, of which power was (Rh) $15 \mathrm{kV}, 230$ to $500 \mu \mathrm{A}$ in the $\mathrm{Na}-\mathrm{Sc}$ region and $50 \mathrm{kV}, 25$ to $70 \mu \mathrm{A}$ in the $\mathrm{Ti}-\mathrm{U}$ region. The exposed area of the ceradon glazes was $10 \mathrm{~mm}$ in diameter. We confirmed that the exposed areas in the celadon glazes did not show the color change. The results are listed in Table II. It is considered that the glazes of the HIZEN celadons are consisted of the similar oxide components of the raw celadon ceramics in Table I, except $\mathrm{CaO}$ and $\mathrm{Fe}_{2} \mathrm{O}_{3}$. It is known that Isubai (natural wood ash) including much $\mathrm{CaCO}_{3}$ is traditionally added into the raw ceramics of the HIZEN celadon glazes. At the first stage of

Table I - Compositions of the raw porcelain ceramics and the raw celadon ceramics at the Arita areas of Izumiyama, Mitunomata, and Ohkawachi.

[Tabela I - Composições das cerâmicas de porcelana e de celadon das áreas Arita de Izumiyama, Mitunomata, e Ohkawachi.]

\begin{tabular}{cccccccc}
\hline wt.\% & $\mathrm{SiO}_{2}$ & $\mathrm{Al}_{2} \mathrm{O}_{3}$ & $\mathrm{~K}_{2} \mathrm{O}$ & $\mathrm{Na}_{2} \mathrm{O}$ & $\mathrm{CaO}$ & $\mathrm{MgO}$ & $\mathrm{Fe}_{2} \mathrm{O}_{3}$ \\
\hline $\begin{array}{c}\text { Izumiyama basic-body ceramics } \\
\text { (Hakujikou) }\end{array}$ & 79.1 & 14.0 & 2.76 & 0.42 & 0.12 & 0.06 & 0.56 \\
Izumiyama celadon ceramics & 73.4 & 15.1 & 4.05 & 3.64 & 0.55 & - & 1.52 \\
Mitunomata basic-body ceramics & 73.6 & 18.4 & 5.58 & 1.10 & 0.24 & - & 0.98 \\
Mitunomata celadon glaze & 63.1 & 15.4 & 5.28 & 0.67 & 12.5 & 0.93 & 1.73 \\
Ohkawachi celadon Ceramics & 67.1 & 21.1 & 5.04 & 1.25 & 0.81 & 0.34 & 4.21 \\
Isubai & 28.7 & 1.43 & 1.72 & 0.60 & 37.8 & 1.29 & 0.32 \\
\hline
\end{tabular}


Table II - Oxide compositions (wt.\%) of the celadon glazes of the HIZEN celadons, Seiji (a)-( $\ell$ ) and the modern Nabeshima celadon (Choshun kiln), Seiji (m).

[Tabela II - Composições de óxidos (peso\%) dos esmaltes de celadon Hizen, Seiji (a)-( $($ ) e do moderno celadon Nabeshima (Choshun kiln), Seiji (m).]

\begin{tabular}{ccccccccccc}
\hline & kiln remain & $\mathrm{SiO}_{2}$ & $\mathrm{Al}_{2} \mathrm{O}_{3}$ & $\mathrm{CaO}$ & $\mathrm{K}_{2} \mathrm{O}$ & $\mathrm{Na}_{2} \mathrm{O}$ & $\mathrm{MgO}$ & $\mathrm{Fe}_{2} \mathrm{O}_{3}$ & $\mathrm{MnO}$ & $\mathrm{TiO}_{2}$ \\
\hline $\mathrm{a}$ & Kamanotsuji & 67.3 & 14.2 & 8.41 & 5.68 & 1.96 & - & 2.15 & 0.15 & - \\
$\mathrm{b}$ & Kamanotsuji & 65.5 & 15.9 & 8.68 & 5.31 & 1.57 & 0.73 & 2.06 & 0.24 & - \\
$\mathrm{c}$ & Hyakuken & 62.8 & 14.9 & 11.8 & 5.39 & 0.78 & 0.86 & 2.73 & 0.32 & 0.18 \\
$\mathrm{~d}$ & Hyakuken & 64.8 & 15.0 & 11.0 & 5.08 & 1.09 & - & 2.35 & 0.32 & 0.17 \\
$\mathrm{e}$ & Nagayoshidani & 64.5 & 15.8 & 10.8 & 4.06 & 0.57 & 1.39 & 2.85 & 0.28 & 0.26 \\
$\mathrm{f}$ & Nagayoshidani & 65.0 & 15.6 & 10.4 & 4.61 & 0.68 & 0.94 & 2.44 & 0.28 & - \\
$\mathrm{g}$ & Maruo & 63.2 & 16.5 & 9.32 & 5.06 & 1.29 & 1.50 & 2.55 & 0.23 & 0.19 \\
$\mathrm{~h}$ & Shimoshirakawa & 67.3 & 15.2 & 9.42 & 3.91 & 0.35 & 1.44 & 2.02 & 0.26 & - \\
$\mathrm{i}$ & Nabeshima kiln & 68.8 & 14.6 & 8.62 & 4.86 & 1.28 & - & 1.60 & 0.11 & - \\
$\mathrm{j}$ & Nabeshima kiln & 69.3 & 16.2 & 5.79 & 5.61 & 1.32 & - & 1.59 & 0.07 & - \\
$\mathrm{k}$ & Higuchi & 68.6 & 15.3 & 6.83 & 5.43 & 1.88 & - & 1.73 & 0.06 & - \\
$\ell$ & Higuchi & 66.6 & 15.4 & 8.13 & 5.74 & 2.02 & - & 1.89 & 0.07 & - \\
$\mathrm{m}$ & Choshun kiln & 75.1 & 12.8 & 4.51 & 4.53 & 2.06 & - & 0.96 & 0.03 & - \\
\hline
\end{tabular}

the celadon production, the ceramic basic-body was heated at about $850{ }^{\circ} \mathrm{C}$. After that, the celadon glaze should be heated at more higher-temperature to make a glassy-phase on the surface of the ceramic basic-body of the HIZEN celadons. The ordinary temperature in the celadon kilns was about 1200$1250^{\circ} \mathrm{C}$ in 1630 's to 1790 's. However, the raw ceramics were not in the glassy state at the temperature region. Thus, $\mathrm{CaCO}_{3}$ is chemically changed to $\mathrm{CaO}$ at about $825^{\circ} \mathrm{C}$, and $\mathrm{CaO}$ has a catalytic function to reduce the glassy temperature of the raw celadon ceramics.

It is known that the characteristic green-brown and bluegreen colors of the celadon glaze in photo 1 are induced by chemical reaction from $\mathrm{Fe}_{2} \mathrm{O}_{3}$ to $\mathrm{FeO}$ in the celadon glazes under the deoxidizing thermal treatment $[16,17]$. As for the present X-ray fluorescence analysis, we can estimate only the atoms emitting X-ray fluorescence, but not electronic valence of its atom for instance $\mathrm{Fe}^{2+}$ and $\mathrm{Fe}^{3+}$. As reported in our other paper [21], we found that, for the HIZEN celadons, there is no chemical reaction from $\alpha-\mathrm{Fe}_{2} \mathrm{O}_{3}$ to $\mathrm{FeO}$ structure under the deoxidizing thermal treatment at high-temperature of about 1200 to $1250^{\circ} \mathrm{C}$. Thus, in Table II, we analyzed the ion oxide as $\mathrm{Fe}_{2} \mathrm{O}_{3}$ in the celadon glazes. It is also found in Table II that there is a content transition of $\mathrm{Fe}_{2} \mathrm{O}_{3}$ and $\mathrm{MnO}$ at Arita and Ohkawachi areas between Photo $1(\mathrm{a})-(\mathrm{h})$ and (i)-(m), that is before and after 1690's year. After 1700's, the technique was gradually declined [14] by the mass production of the HIZEN colored porcelains at the Arita areas. It is considered that the celadon declination after 1700's induced originally the elegant celadon glaze of white-green-brown at Arita and of bluegreen at Ohkawachi. However, the color difference can not be confirmed in Table II, as Photo 1(i), (j); Nabeshima-domain kiln (Ohkawachi, 1690-1720's), (k), ( $\ell$ ); Higuchi (Arita, 17601790's), and (m), (n); Choshun kiln (2007).

\section{EXPERIMENTAL}

In order to study the structural properties of the HIZEN celadons, we used a high resolution 4-circle X-ray diffractometer using synchrotron radiation at the Pohang Light Source (2.5 GeV) of the Pohang Accelerator Laboratory (Korea). After setting the broken piece of the HIZEN celadons in photo 1 on the specimen stage of the 4-circle $\mathrm{X}$-ray diffractometer, we irradiated its glaze with the incident monochromatic X-ray beams of about $1 \mathrm{~mm}$ in diameter. As described before, all of the used pieces of the HIZEN celadons in photo 1 were rented from the public museum. Thus, we preliminary checked the color modulation of the irradiated celadon glaze, induced by strongly high-bright $\mathrm{X}$-ray of the incident synchrotron radiation. It was experimentally confirmed that its X-ray photon energy of about $8.0457 \mathrm{keV}$ $(1.5412 \AA$ Á) did not effect any color change of the irradiated galze. The used X-ray diffraction method was a $2 \theta$ scan with each stepping angle of $\Delta 2 \theta=0.03$ degrees in the region of $2 \theta=10.00$ to 70.00 degrees, where the specimen was always fixed at an incident angle $\theta_{\mathrm{s}}$ of about 5 degrees to the incident $\mathrm{X}$-ray beams during measurements.

\section{RESULTS AND DISCUSSION}

Figs. 1a and $\mathrm{b}$ show the X-ray diffraction patterns of the raw celadon ceramics, called celadon ceramics, taken at Izumiyama (Arita) and Ohkawachi (Imari), respectively. The diffraction patterns are largely different, though the component ratio of the oxides between both areas is not so largely changed in Table I.

In Fig.1a peaks denoted by "Q" result from reflections of the quartz- $\mathrm{SiO}_{2}$ structure and show a similar intensity 

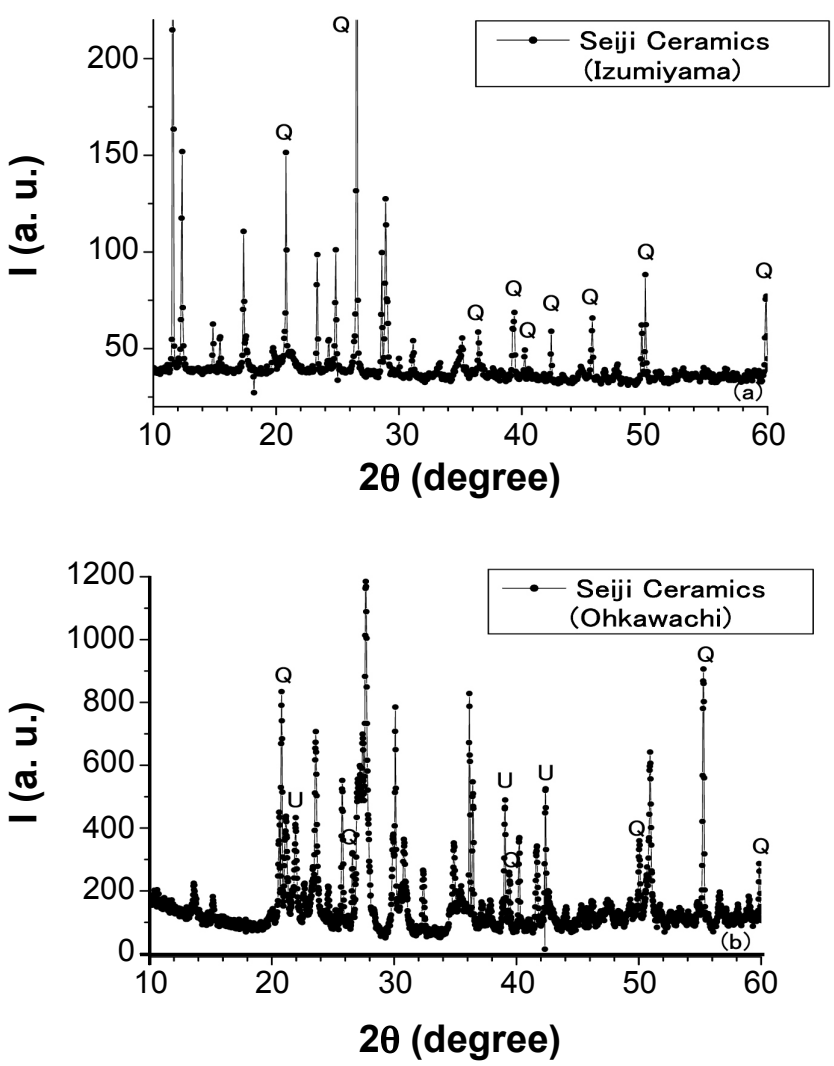

Figure 1: X-ray diffraction patterns of the raw celadon ceramics;(a) Izumiyama at Arita and (b) Ohkawachi at Imari.

[Figura 1: Difratogramas de raios $X$ da matéria-prima cerâmica celadon; (a) Izumiyama em Arita e (b) Ohkawachi em Imari.]

distribution of the $\mathrm{SiO}_{2}$ structure. However, the other observed peaks could not be related to the component oxides of $\mathrm{Al}_{2} \mathrm{O}_{3}, \mathrm{CaO}, \mathrm{K}_{2} \mathrm{O}, \mathrm{Na}_{2} \mathrm{O}, \mathrm{MgO}$, while some weak peaks result from the $\mathrm{Fe}_{2} \mathrm{O}_{3}$ structure. We also confirmed that the observed peaks are not related to feldspar complexes of $\left(\mathrm{SiO}_{2}-\mathrm{Al}_{2} \mathrm{O}_{3}\right)$ system; $\mathrm{KAlSi}_{3} \mathrm{O}_{8}$ (orthoclase), $\mathrm{KAlSi}_{3} \mathrm{O}_{8}$ (microcline), $\mathrm{NaAlSi}_{3} \mathrm{O}_{8}$ (albite), (K,Na) $\mathrm{Si}_{3} \mathrm{O}_{8}$ (sanidine), $(\mathrm{Na}, \mathrm{K}) \mathrm{Si}_{3} \mathrm{O}_{8}$ (anorthoclase), $\mathrm{CaAl}_{2} \mathrm{Si}_{2} \mathrm{O}_{8}$ (anorthite), of which volcanic minerals are universally included in the earth crust. Thus, it is considered that the Izumiyama ceramics has a characteristic structure of $\left(\mathrm{SiO}_{2}-\mathrm{Al}_{2} \mathrm{O}_{3}\right)$ complex, in which the main oxide is Quartz- $\mathrm{SiO}_{2}$. However, at a moment, we cannot analysis all of the observed peaks in Fig.1a, except the $\mathrm{Fe}_{2} \mathrm{O}_{3}$ peaks. In Fig.1b, peaks denoted by "Q" result from reflections of the quartz- $\mathrm{SiO}_{2}$ structure. However, the intensity of the $\mathrm{SiO}_{2}$ peaks is not reflected on the intensity taken by the quartz-SiO ${ }_{2}$ structure. Thus, we consider that the quartz fine crystals are distributed under the disorder orientation in the Ohkawachi ceramics. The other observed peaks, except peaks denoted by "U", result from the (K,Na) $\mathrm{Si}_{3} \mathrm{O}_{8}$ (sanidine) structure and show a similar intensity distribution of the sanidine structure. The $U$ peaks could not be identified by the component oxides and the feldspar complexes.

As described before, the glaze color of the HIZEN celadons is slightly different between the Yamauchi and
Arita areas and the Ohkawachi area. In photo 1 the former is green-brown while the later is blue-green. We suspect that the difference depends on the structural property of the raw ceramic materials. When producing the HIZEN celadons at
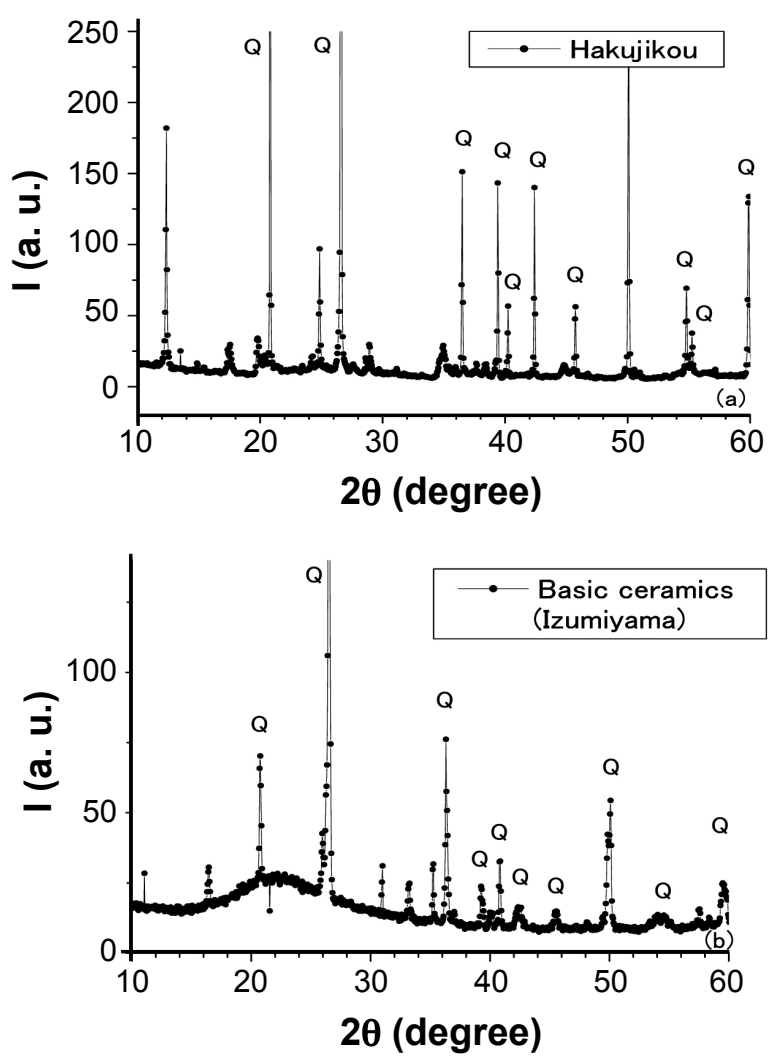

Figure 2: X-ray diffraction patterns of Izumiyama ceramics; (a) Hakujikou and (b) the basic-body ceramics.

[Figura 2: Difratogramas de raios $X$ das cerâmicas Izumiyama; (a) Hakujikou e (b) cerâmica base.]

Arita, the basic body was made from Hakujikou, Izumiyama basic ceramics of high-quality, by heating at about $850{ }^{\circ} \mathrm{C}$. Fig. 2a shows the X-ray diffraction patterns of Hakojikou. The raw material is mainly the quartz- $\mathrm{SiO}_{2}$, as the Izumiyama Seiji ceramics in Fig.1a. Fig. 2b shows the X-ray diffraction patterns of the basic body of the HIZEN ceradon. We found that the $850{ }^{\circ} \mathrm{C}$ thermal treatment increases the quartz$\mathrm{SiO}_{2}$ structure in the basic-body ceramics. Furthermore, the diffraction patterns of halo-like scattering also indicate a glass state in the basic body. The glass state is made of the other oxides, except quartz- $\mathrm{SiO}_{2}$.

The white-color of the basic-body ceramics increases optically the brightness of the ceramic glaze. However, the raw celadon ceramics are not melted even at about $1200-1250{ }^{\circ} \mathrm{C}$. At that time, the potters used empirically a ceramic technique to make the glaze of glassy phase on the ceramic basic-body of the HIZEN celadons. They added Isubai, including much $\mathrm{CaCO}_{3}$, into the raw ceramics in Table II. In order to study the structural property of the glazes of the present celadons by means of the nondestructive method, we carried out measurements of the X-ray diffraction patterns using the 

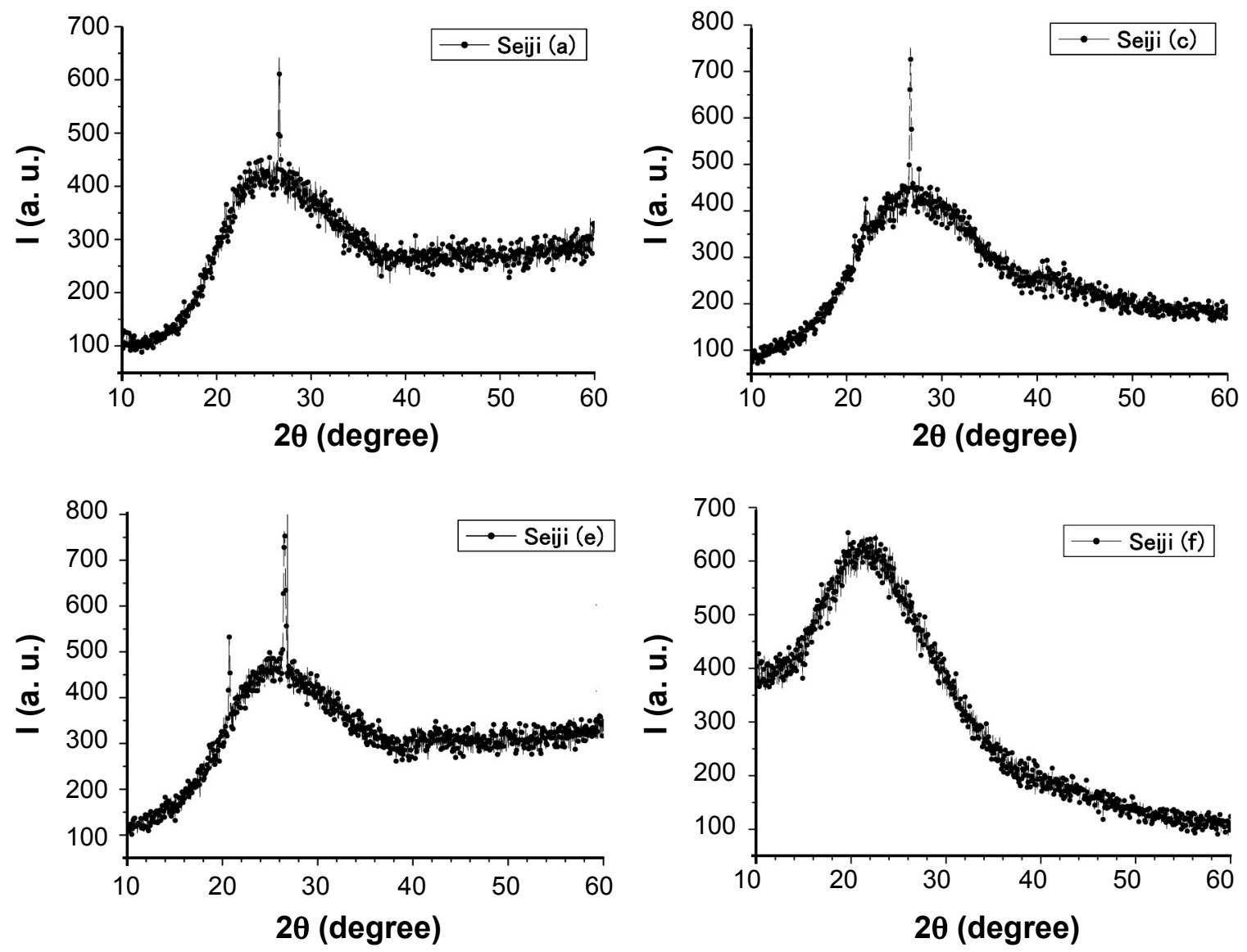

Figure 3: X-ray diffraction patterns of the HIZEN celadon glazes; Seiji (a), (c), (e), and (f), which are in photo 1 (a), (c), (e) and (f), respectively.

[Figura 3: Difratogramas de raios X dos esmaltes de celadons HIZEN; Seiji (a), (c), (e), e (f), que são na foto 1 (a), (c), (e) $e(f)$, respectivamente.]

synchrotron radiation. The diffraction method was a $2 \theta$ scan with each stepping angle of $\Delta 2 \theta=0.03$ degrees in the region of $2 \theta=10.00$ to 60.00 degrees, where the specimen was always fixed at an incident angle $\theta_{\mathrm{s}}$ of about 5 degrees to the incident monochromatic X-ray beams during the measurements. Fig. 3 shows X-ray diffraction patterns of the HIZEN celadon glazes; Seiji (a), (c), (e), and (f), which are in photo 1 (a), (c), (e) and (f), respectively. Seiji (a) and (c) were produced in 1630-1640's, while Seiji (e) and (f) in 1655-1660's. All of the diffraction patterns show halo-like scatterings. This suggests that the celadon glazes are in glassy state. Thus, the component oxides in Table II are melted and/or resolved to make the short-range order of atoms in the celadon glazes, by heating at about 1200 to $1250{ }^{\circ} \mathrm{C}$. However, we observed the peaks of the quartz- $\mathrm{SiO}_{2}$ structure for Seiji (a), (c) and (e), but not (f) in Fig. 3. We suspect that the short-range order of component atoms and the quartz- $\mathrm{SiO}_{2}$ fine crystals in the celadon glazes affect the color of green-brown and the color uniformity in Seiji (a), (c), (e), and (f).

Fig. 4 shows X-ray diffraction patterns of the HIZEN celadon glazes; Seiji $(\mathrm{h}),(\mathrm{j}),(\ell)$, and $(\mathrm{m})$, which are in photo $1(\mathrm{~h}),(\mathrm{j}),(\ell)$, and $(\mathrm{m})$, respectively. Seiji $(\mathrm{h}),(\mathrm{j})$, and $(\ell)$ were produced in 1655-1660's, 1690-1720's, 1760-1790's, respectively, while Seiji $(m)$ in 2007. Seiji $(h)$ and $(\ell)$ were produced at Arita, while Seiji (j) and (m) at Ohkawachi. All of the diffraction patterns show halo-like scatterings. This suggests that the celadon glazes are in glassy state. We also observed the peaks of the quartz- $\mathrm{SiO}_{2}$ structure for Seiji (h) and $(\ell)$. However, the peaks of Seiji $(\mathrm{j})$ and $(\mathrm{m})$ does not result from quartz- $\mathrm{SiO}_{2}$. After identifying the peaks with the feldspar complexes of $\left(\mathrm{SiO}_{2}-\mathrm{Al}_{2} \mathrm{O}_{3}\right)$ system, we consider that the peaks of Seiji $(\mathrm{j})$ and $(\mathrm{m})$ result from the orthoclase structure of $\mathrm{KAlSi}_{3} \mathrm{O}_{8}$ or the sanidine structure of $(\mathrm{K}, \mathrm{Na})$ $\mathrm{Si}_{3} \mathrm{O}_{8}$. Thus, we suspect that, in photo 1 , the glassy glazecolor of the HIZEN celadons depends on the raw basic ceramics taken at Izumiyama and Ohkawachi, where the farmer is mainly quartz- $\mathrm{SiO}_{2}$ and the later is sanidine as a main oxide component.

Table I shows the oxide components in the glazes of the HIZEN celadons. The component ratios do not give information of the color brightness of the celadon glaze. On the other hand, the X-ray diffraction patterns suggest the structural information of the basic-body ceramics and the glassy celadon glazes. It is known that the glaze color depends on the very small amount transition-metal ions of $(\mathrm{Cr}, \mathrm{Mn}, \mathrm{Cu}, \mathrm{Zn})$, called the extra transition-metal ions, 

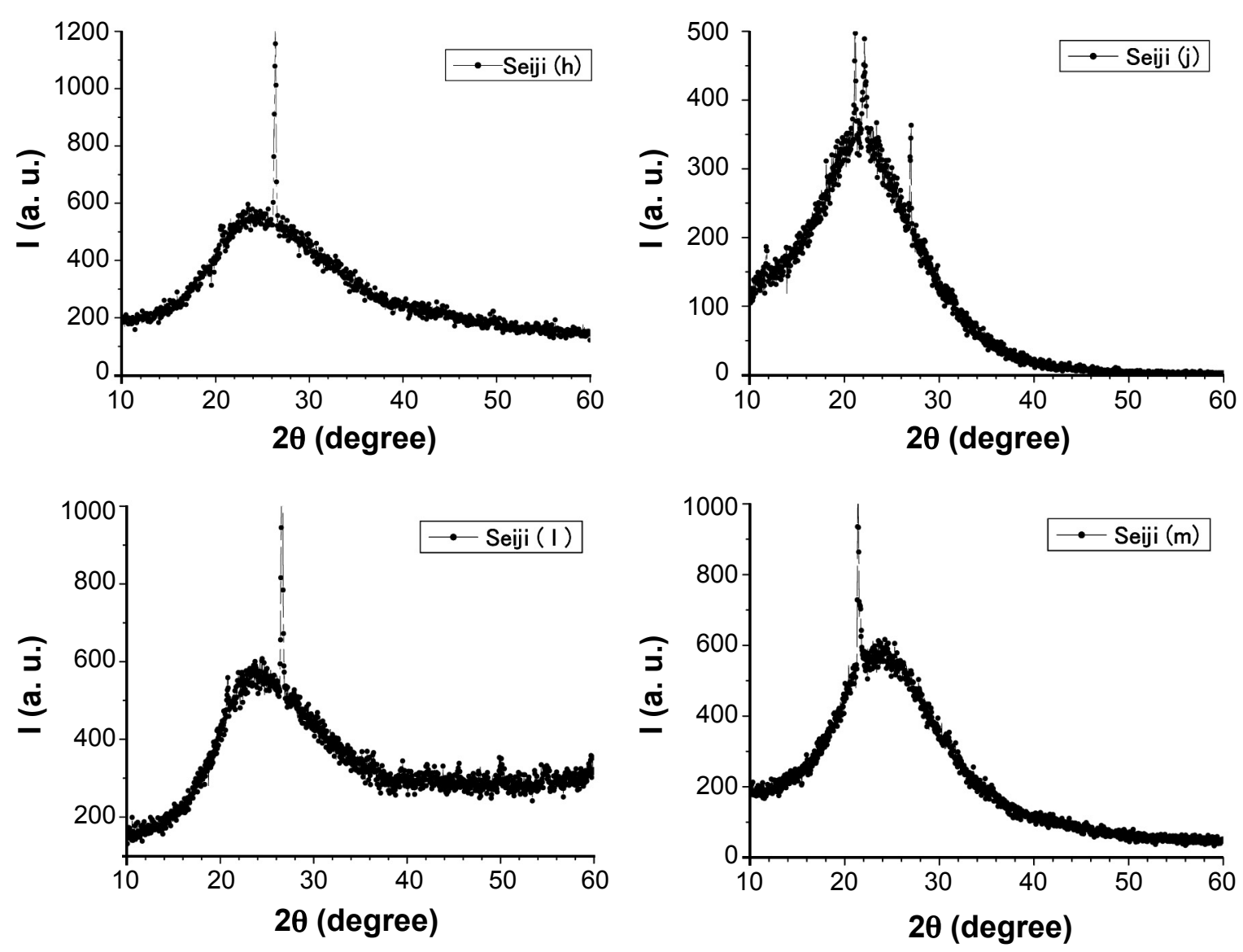

Figure 4: X-ray diffraction patterns of the HIZEN celadon glazes ; Seiji (h), (j), $\ell$ ), and the modern Nabeshima celadon (Choshun kiln), Seiji (m).

[Figura 4: Difratogramas de raios $X$ dos esmaltes dos celadons HIZEN; Seiji (h), (j), l), e os modernos celadons Nabeshima (forno Choshun), Seiji (m).]

in the celadon glazes, in addition to Fe ions. However, the component oxides were melted or resolved to make the glassy short-range order of the ions in the celadon glazes, except the small amount fine crystals of quartz-SiO ${ }_{2}$ (Izumiyama celadon ceramics) and feldspar of orthoclase or sanidine (Ohkawachi celadons ceramics) in Figs. 3 and 4. Thus, we can only estimate whether the impurity-like extra transitionmetal ions exist in the glassy celadon glaze. If so, we deduce that, in 1630's to 1790's (the Edo period), the potters added naturally or artificially the extra transition-metal oxides into the raw basic ceramics, to induce the elegant and bright color of the celadon glaze. As in Table II, it is not easy to detect the very small amount of the extra transition-metal ions by means of the present ordinary X-ray fluorescence analyzer. Thus, we carried out measurements of X-ray absorption spectrum XAS in the wider energy region of the monochromatic incident X-ray beams of synchrotron radiations, in order to detect the transition metal ions of $(\mathrm{Cr}, \mathrm{Mn}, \mathrm{Co}, \mathrm{Ni}, \mathrm{Cu}, \mathrm{Zn})$ in the glassy celadon glazes.

We measured XAS of the HIZEN celadons and the modern Nabeshima-Choshun celadons in photo 1, by using synchrotron radiation at the Pohang Light Source $(2.5 \mathrm{GeV})$. A double crystal monochromator of $\mathrm{Si}$ (111) gave a relative energy resolution $\Delta \mathrm{E}$ to be less than about $0.2 \mathrm{eV}$ at the respective monochromatic incident $\mathrm{X}$-ray beams. The incident $\mathrm{X}$-ray photons $\left(\mathrm{I}_{\mathrm{o}}\right)$ were detected with an ionic chamber set before the specimens of the broken pieces in photo 1 , while the $\mathrm{X}$-ray fluorescence photons $\left(\mathrm{I}_{\mathrm{F}}\right)$ emitted from the front surface of the specimens were simultaneously detected with an X-ray fluorescence detector. The surface was always set with about $45.0^{\circ}$ to the incident X-ray beam, of which the size was about 1 to $3 \mathrm{~mm}$ in horizontal and $1 \mathrm{~mm}$ in vertical on the specimen surface to the electron orbital of the accelerator. Figs. 5 a, b, c show the XAS of Seiji $(\mathrm{g})$ measured in the wider region of 5900 to $8000 \mathrm{eV}$. The large change of the spectrum occurs at 7120 $\mathrm{eV}$ to be a Fe-K edge, while there are two other small changes denoted by arrows at about 5993 and $6547 \mathrm{eV}$ to be $\mathrm{Cr}-\mathrm{K}$ and Mn-K edges, respectively. In Fig.5 the gap of the detected X-ray photon counts $\left(\mathrm{I}_{\mathrm{F}} / \mathrm{I}_{\mathrm{o}}\right)$ is about $0.403,0.020,0.0011$ to $\mathrm{Fe}, \mathrm{Mn}, \mathrm{Cr}-\mathrm{K}$ edge, respectively. On the other hand, Figs. 6 a, $\mathrm{b}, \mathrm{c}$ show the XAS of Seiji $(\mathrm{g})$ measured in the wider region of 8400 to $10200 \mathrm{eV}$. There are two small changes at about 8988 and $9661 \mathrm{eV}$ to be $\mathrm{Cu}-\mathrm{K}$ and $\mathrm{Zn}-\mathrm{K}$ edges, respectively. In Fig. 6 the gap of the detected X-ray photon counts $\left(\mathrm{I}_{\mathrm{F}} / \mathrm{I}_{\mathrm{o}}\right)$ is about $0.0012,0.0007$ to $\mathrm{Cu}, \mathrm{Zn}-\mathrm{K}$ edge, respectively. Thus, it is found that Seiji (g) includes naturally or artificially the very small amount of $\mathrm{Cr}, \mathrm{Cu}$, and $\mathrm{Zn}$, in addition to the small amount $\mathrm{Fe}$ and $\mathrm{Mn}$. 
We also carried out measurements of the XAS in the wider energy region of 5900 to $10200 \mathrm{eV}$ for the HIZEN celadons, Seiji (a) to (n) in photo 1 (a) to (n). The results are listed in Table III. Although it is not easy to accurately represent the characteristic color of the celadon glazes, we used some color-representations contributing its color
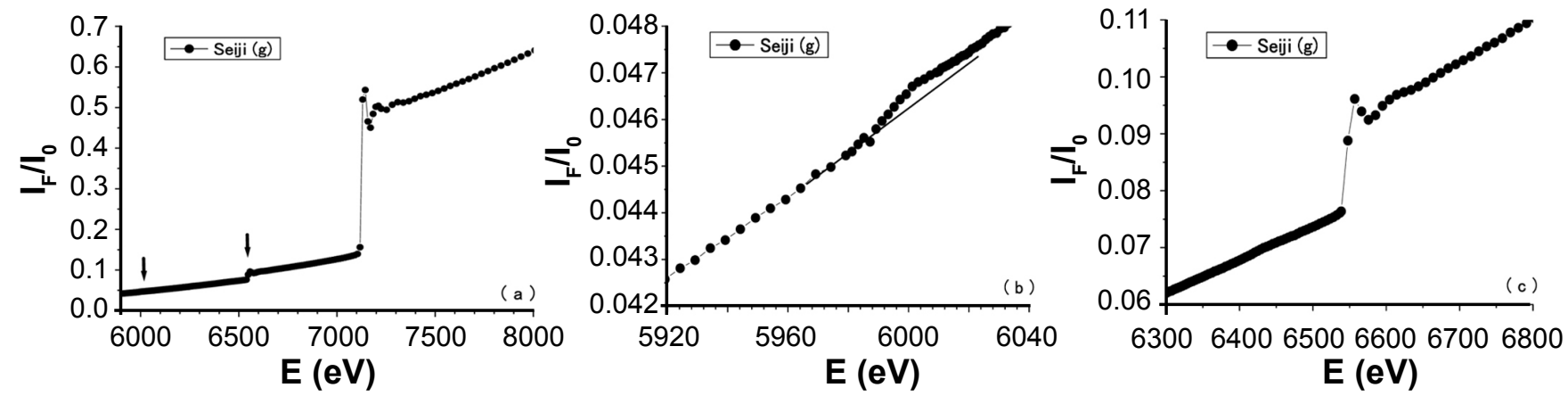

Figure 5: X-ray absorption spectra in the wider region of 5900 to $8000 \mathrm{eV}$ for the HIZEN celadon glaze, Seiji (g).

[Figura 5: Espectros de absorção de raios X na larga região de 5900 a 8000 eV do esmalte de celadon HIZEN, Seiji (g).]
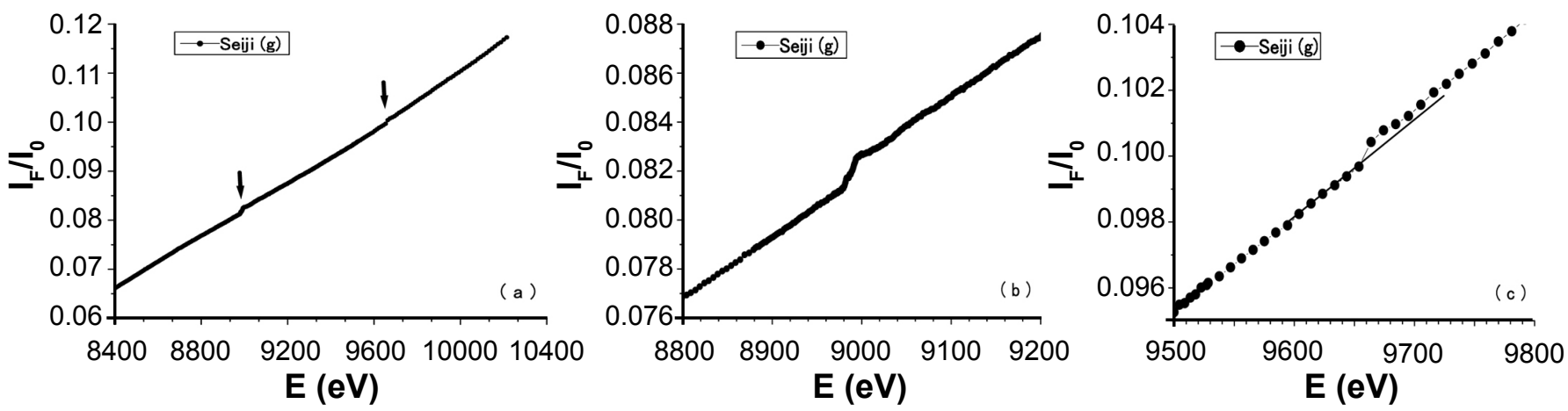

Figure 6: X-ray absorption spectrum in the wider region of 8400 to $10200 \mathrm{eV}$ for the HIZEN celadon glaze, Seiji (g).

[Figura 6: Espectros de absorção de raios X na larga região de 8400 a 10200 eV do esmalte de celadon HIZEN, Seiji (g).]

Table III - Correlation between the colored brightness and the transition metal ions included in the glazes of the HIZEN celadons Seiji (a)-( $\ell$ ), and the modern Nabeshima celadon (Choshun kiln), Seiji (m),(n).

[Tabela III - Correlação entre o brilho da coloração e os íons de metal de transição incluídos nos esmaltes

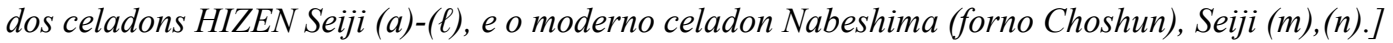

\begin{tabular}{ccccc}
\hline & kiln place & year & transition metal & glaze color \\
\hline a & Yamauchi & $1630-1640$ 's & $\mathrm{Mn}, \mathrm{Fe}, \mathrm{Cu}$ & white-green-brown \\
b & Yamauchi & $1630-1640$ 's & $\mathrm{Mn}, \mathrm{Fe}, \mathrm{Cu}, \mathrm{Zn}$ & white-green-brown \\
c & Yamauchi & $1630-1640$ 's & $\mathrm{Mn}, \mathrm{Fe}, \mathrm{Cu}, \mathrm{Zn}$ & black-green-brown \\
d & Yamauchi & $1630-1640$ 's & $\mathrm{Mn}, \mathrm{Fe}, \mathrm{Cu}, \mathrm{Zn}$ & black-brown \\
e & Arita & $1655-1660$ 's & $\mathrm{Mn}, \mathrm{Fe}, \mathrm{Cu}$ & green-brown \\
f & Arita & $1655-1660$ 's & $\mathrm{Mn}, \mathrm{Fe}, \mathrm{Cu}$ & white-green-brown \\
g & Arita & $1650-1660$ 's & $\mathrm{Cr}, \mathrm{Mn}, \mathrm{Fe}, \mathrm{Cu}, \mathrm{Zn}$ & white-green-brown \\
h & Arita & $1655-1660$ 's & $\mathrm{Cr}, \mathrm{Mn}, \mathrm{Fe}, \mathrm{Cu}, \mathrm{Zn}$ & white-green-brown \\
i & Ohkawachi & $1690-1720$ 's & $\mathrm{Cr}, \mathrm{Mn}, \mathrm{Fe}$ & blue-green \\
j & Ohkawachi & $1690-1720$ 's & $\mathrm{Cr}, \mathrm{Mn}, \mathrm{Fe}$ & blue-green \\
k & Arita & $1760-1790$ 's & $\mathrm{Cr}, \mathrm{Mn}, \mathrm{Fe}, \mathrm{Cu}, \mathrm{Zn}$ & white-blue- green-brown \\
$\ell$ & Arita & $1760-1790$ 's & $\mathrm{Cr}, \mathrm{Mn}, \mathrm{Fe}, \mathrm{Cu}, \mathrm{Zn}$ & white-blue- green-brown \\
m & Ohkawachi & 2007 & $\mathrm{Cr}, \mathrm{Mn}, \mathrm{Fe}$ & white-blue-green \\
n & Ohkawachi & 2007 & $\mathrm{Cr}, \mathrm{Mn}, \mathrm{Fe}$ & white-blue-green \\
\hline
\end{tabular}


emission of the HIZEN celadon glazes in photo 1. Table III suggests that, after about 1660's year, Cr of very small amount is contained in the celadon glaze at Arita, as those of the Nabeshima celadon glazes; Seiji (i), (j) of Nabeshimadomain kiln (1690-1720's) and Seiji (m), (n) of Choshun kiln (2007). Thus, we also suspect that the glaze colors of greenbrown and blue-green depend partially on the content of $\mathrm{Cu}$ and $\mathrm{Cr}$, respectrively, in addition to the structural properties of the raw basic ceramics and the glassy celadon glazes.

\section{CONCLUSIONS}

In order to study the historical and geometrical correlation among the glazes of the HIZEN celadons including the modern Nabeshima celadon (Choshun kiln), we carried out the X-ray fluorescence analysis, the X-ray diffraction, and the measurements of the X-ray absorption spectra near the X-ray $\mathrm{K}$-edge of the transition metal ions in the wider energy region of the incident X-ray photons, by using the synchrotron radiation. The X-ray fluorescence analysis in Table II suggested that, in 1630's to 1790 's, the potters added the Isubai (natural wood ash) including much $\mathrm{CaCO}_{3}$ into the raw ceramics of the HIZEN celadon at Izumiyama (Arita) and Ohkawachi (Imari), to make the glassy celadon glaze coated the surface of the celadon basic body. We found from the X-ray diffraction patterns that the $\mathrm{CaO}$, changed chemically from $\mathrm{CaCO}_{3}$ at about $825^{\circ} \mathrm{C}$, certainly reduced the glassy temperature of the raw celadon ceramics at about $1200-1250{ }^{\circ} \mathrm{C}$ in the ancient HIZEN kilns. We suspected that the glaze color of the HIZEN celadons strongly depends on the structural property of the Izumiyama basic ceramics and the Ohkawachi ones, where the former was mainly Quartz- $\mathrm{SiO}_{2}$, and the later was Sanidine $\left((\mathrm{K}, \mathrm{Na}) \mathrm{Si}_{3} \mathrm{O}_{8}\right)$.

The X-ray absorption spectra in the wider energy region (Table 3) suggested that the characteristic color of the present celadons is related to the contained transition metal ions $(\mathrm{Cr}$, $\mathrm{Cu}, \mathrm{Zn}$ ) of very small amount in the glazes, in addition to $\mathrm{Fe}$ and $\mathrm{Mn}$ of small amount. We suspected that, for the glaze of the HIZEN celadons, $\mathrm{Cu}$ partially gives the green-brown color, while $\mathrm{Cr}$ induces the blue-green color. It is possible to considered that the potters added naturally or artificially the extra transition-metal $(\mathrm{Cr}, \mathrm{Mn}, \mathrm{Cu}, \mathrm{Zn})$ oxides into the raw basic ceramics of the HIZEN celadons, to induce the elegant and bright color of the celadon glaze. However, at a moment, we could not identify the chemical format of the extra oxides, because their amounts are very small amount in the glassy glazes of the present celadons. The other reason is as follows; in the present investigations, we were strongly requested to use nondestructive methods for studying the structural and electronic properties of the present celadons. Thus, we could not take out the partial glazes from the HIZEN celadons for the chemical analysis.

\section{REFERENCES}

[1] I. Ogi, From Early Imari to Kokutani-style, Soujusha Bijutushuppan (1990).
[2] The Kyushu Ceramic Museum, Polychrome porcelain in Hizen - its early type and change of style (1991).

[3] H. Nishida, Y. Ohhashi, Old Imari ware, The Sun special issue 63, Autum '88, Heibonsha (1994).

[4] I. Ogi, Imari, Ribun Shuppan (2000).

[5] C. Shimizu, La Porcelaine Japonaise, Massin (2002).

[6] The Society of Kyshu Early Modern Ceramic Studies, Hizen Porcelains in Japan (2002).

[7] K. Ohashi, M. Arakawa, Early Imari, the origins of Underglaze Cobalt-blue and Overglaze Polychrome Enamels, Japan Broadcasting Corporation (NHK) (2004).

[8] The Kyushu Ceramic Museum, Nabeshima, Porcelain for the Shogunate (2006).

[9] A. Imai, Celadon, Issue 4, Chinese wares, Heibonsha (2002).

[10] Wang Qing-zheng, Fan Dong-quing, Zhou Li-li, The Discovery of Ru Kiln, a Famous Song-ware Kiln of China, The Woods Piblishing Co. (1991).

[11] K. Ohashi, HIZEN celadons, Japanese Seiji, The Kyushu Ceramic Museum (1989).

[12] K.Takeuchi, T. Nobayashi, S. Morokuma, H.Tsuzuki, Development of old-fashined porcelain with traditional raw material II - Characteristic feature on the body and glaze of Hasami celadon, Annual Report of Ceramic Reserch Center of Nagasaki 48 (2001).

[13] Y. Nakano, MITUMATA Seiji Kiln, Hasami Cultural properties report 10, Hasami-cho Boad of Education (1998).

[14] K. Ohashi, Arita and Imari porcelains, Tankosha (2002).

[15] Y. Suzuta, IMARI CERADON, Old Imri Series П, KoImari Publication (1991).

[16] J. S. Larid, The composition of Chinese celadon pottery, J. Am. Ceram. Soc. 1 (1918) 675-678.

[17] R. R. Hunghan, Early Chinese ceramics glazes, Ceram. Age 56 (1950) 40.

[18] M. Hidaka, K. Ohashi, S. Kajihara, R. P. Wijesundera, L. S. R. Kumara, Jae-Young Choi, Nark Eon Sung, Structural properties of the red-color overglaze for the HIZEN porcelains produced in the early Edo period of Japan, Ceram. Int. 35 (2009) 875-886.

[19] M. Hidaka, H. Horiuchi, K. Ohashi, R. P. Wijesundera, L. S. R. Kumara, Jae-Young Choi, Yong Jun Park, Structural properties of the red-color overglazes on the Kakiemon-style porcelains produced in the later $17^{\text {th }}$ century by means of X-ray diffraction (I), Cerâmica 55, 334 (2009) 120-127.

[20] M. Hidaka, H. Horiuchi, K. Ohashi, R. P. Wijesundera, L. S. R. Kumara, Nark Eon Sung, Local structures and electronic band states of $\alpha-\mathrm{Fe}_{2} \mathrm{O}_{3}$ polycrystalline particles included in the red-color overglazes and the transparent glazes of the Kakiemon-style porcelains by means of X-ray absorption spectra (II), Cerâmica 55, 335 (2009) 223-232.

[21] M. Hidaka, K. Ohashi, R. P. Wijesundera, L. S. R. Kumara,S. Sugihara, N. Momoshima, Nark Eon Sung, Local structures and electronic band states of $\alpha-\mathrm{Fe}_{2} \mathrm{O}_{3}$ polycrystalline particles in the glazes of the HIZEN celadons produced in the Edo period of Japan, by means of X-ray absorption spectra (II), to be submitted Cerâmica (2009).

(Rec. 03/02/2010, Ac. 28/05/2010) 